ElementerIs: Jurnal Ilmiah Pendidikan Dasar Islam

Volume 2 Nomor 2 November 2020

e-ISSN: 2655-6324

\title{
PENERAPAN SISTEM FULL DAY SCHOOL DI MI KOTA MALANG
}

\author{
Binti Masrurotul Ainiah \\ Universitas Islam Malang \\ e-mail: bintimasrurotulaini@gmail.com
}

Diterima: 30 Juli 2020 I Direvisi: 29 Agustus 2020 I Disetujui: 2 September 2020 (C) 2020 Pendidikan Guru Madrasah Ibtidaiyah Fakultas Agama Islam Universitas Islam Malang

\begin{abstract}
The formation and development of characters from an early age is very necessary, hence the importance of education to direct student to develope positive character in both the scope of religion and nasionalism by practicing character values in daily life. One alternative for the development of students character is by implementing a full day school system which means students are involved in school activities for one full day starting at 06.45 a.m. until 3.00 p.m as has been applied at MI Khadijah Malang. This study used a method with 3 instruments, namely: interview, observation and documentation. This study also aims to discribe: 1). Character of MI Khadijah Malang students, 2). The process of carrying out a full day school in developing character at MI Khadijah, 3). Supporting and inhibiting factors in the process of implementing full day school at MI Khadijah Malang. And the result of this study showed that broadly the character of students in MI Khadijah classified as students who where easily directed and conditioned by the application of full day school, teacher will be ease to supervise and guide students in character development through habituation of activities carried out school regularly.
\end{abstract}

Keywords: Full day school, Character, Education.

\begin{abstract}
Abstrak
Pembinaan dan pengembangan karakter sejak usia dini sangat diperlukan, maka dari itu pentingnya pendidikan untuk mengarahkan siswa mengembangkan karakter yang positif baik dalam lingkup agama maupun nasionalisme dengan mengamalkan nilainilai karakter dalam kehidupan sehari-hari. Salah satu alternatif untuk pengembangan karakter siswa adalah dengan menerapkan sistem full day school yaitu siswa dilibatkan dalam kegiatan sekolah selama satu hari penuh mulai pukul 06.45 hingga 15.00 sebagaimana yang diterapkan di MI Khadijah Malang. Penelitian ini menggunakan metode dengan 3 instrumen yaitu: wawancara, observasi dan dokumentasi. Penelitian ini juga bertujuan untuk mendeskripsikan: 1). Karakter siswa MI Khadijah Malang, 2). Proses pelaksanaan full day school dalam pembinaan karakter di MI Khadijah, 3). Faktor pendukung dan penghambat dalam proses pelaksanaan full day school di MI Khadijah Malang. Dan hasil penelitian ini
\end{abstract}

This work is licensed under Creative Commons Attribution Non Commercial 4.0 International License Available online on: http://riset.unisma.ac.id/index.php/je 
menunjukkan bahwa secara garis besar karakter siswa di MI Khadijah tergolong siswa yang dimana dengan mudah diarahkan dan dikondisikan dengan penerapan full day school, guru akan dimudahkan dalam mengawasi dan membimbing siswa dalam pengembangan karakter melalui pembiasaan kegiatan yang dilakukan. keluar sekolah secara teratur.

Kata kunci: Full day school, karakter, Pendidikan.

\section{Pendahuluan}

Kualitas sumber daya manusia merupakan hal yang penting dalam keberhasilan suatu bangsa untuk memperoleh tujuan tertentu, maka dari itu untuk meningkatkan kualitas sumber daya manusia maka perlunya lembaga pendidikan sebagai wadah utama dalam mencetak generasi bangsa yang baik. Menurut Sudarsa (2013:6) "pendidikan bukan hanya sekedar memberdayakan pikiran dan pencapaian prestasi belajar melainkan berkaitan juga dengan hati nurani, moral spiritual serta pembentukan karakter". Pendidikan disini tidak hanya mengembangkan aspek kognitif melainkan juga memberdayakan aspek secara religius dan yang paling penting adalah berpendidikan karakter tujuanya adalah agar manusia memiliki moral yang baik, sesuai dengan nilai-nilai agama dan juga nilai-nilai bangsa dengan landasan pancasila.

Seiring dengan berjalanya waktu dan berkembangnya zaman berbagai macam problematika dalam dunia terus berkembang terlebih lagi pada dunia pendidikan, dimana pendidikan sudah seharusnya dijadikan prioritas pemerintah dan menjadi perhatian bagi masyarakatnya. Menurut Nelson Mandela dalam Sulistiono (2017:96) mengatakan "education is the most powerful weapon which you can use to change the world" dalam gambaran umumnya pendidikan adalah senjata yang ampuh yang bisa digunakan untuk merubah dunia, artinya jika kita terus memperbaiki sistem pendidikan khususnya di Indonesia maka hal yang bisa terjadi adalah dapat membawa perubahan dalam peradaban suatu bangsa lebih baik.

Anak adalah aset bagi masa depan suatu bangsa, maka dari itu perlunya pengarahan, pembentukan dan penanaman nilai-nilai positif sejak dini. Menurut Sigmund Freud dalam Sudarsa (2013:6) "karakter yang berkualitas harus dibentuk sejak usia dini, kegagalan dalam penanaman kepribadian yang baik di usia dini akan membentuk pribadi-pribadi yang bermasalah kelak dimasa dewasanya", artinya pada usia dini anak akan mudah meniru dan mengingat jika hal tersebut terus dilakukan, oleh sebab itu guru harus memberikan contoh serta pengarahan yang positif pada peserta didik, karena untuk membangun karakter suatu bangsa 
membutuhkan waktu yang lama dan harus dilakukan secara berulang dan menyeluruh.

Menurut Setiawan dan Sulistiani, I.R (2019:36) "pengembangan budaya dan karakter bangsa tidak akan mungkin dimasukkan sebagai unsur yang terpisah dalam pokok bahasan, tetapi harus melalui proses integrasi ke dalam mata pelajaran pengembangan diri, dan budaya sekolah". Artinya adanya keterkaitan antara pengembangan budaya dengan pembelajaran yang ada disekolah.

Maka dari itu adanya persaingan lembaga sekolah baik dari kalangan Sekolah Dasar, Sekolah Menengah Pertama dan Sekolah Menengah Atas saling berlombalomba untuk mewujudkan pendidikan yang dianggap mampu untuk membentuk karakter peserta didik dan dapat mengembangkan aspek kognitif, dan keterampilanya untuk lebih maju, mampu bersaing dan bertahan hidup dalam menghadapi era globalisasi salah satunya adalah penerapan sistem full day school. Menurut Arifin dalam Munawaroh (2015:5) "pembelajaran dengan sistem full day school mengharuskan sekolah merancang perencanaan pembelajaran dari pagi hingga sore". Dari situ dapat disimpulkan bahwa sistem full day school merupakan ciri khas sekolah terpadu yang pelaksanaan pembelajaran dimulai dari pagi hingga sore hari.

Konsep full day school merupakan salah satu solusi dari kegelisahan yang dialami masyarakat terkait dengan rusaknya moral anak bangsa, dari data yang telah ditemukan oleh Badan Pusat Statistik (BPS) memaparkan bahwasanya pada tahun 2013 tingkat kenakalan remaja di Indonesia mencapai 6325 kasus, sedangkan pada tahun 2014 jumlahnya mencapai 7007 kasus, dan pada tahun 20157762 kasus, artinya dari tahun ke tahun kenakalan remaja selalu mengalami kenaikan dan kasus tersebut terdiri dari berbagai kasus kenakalan remaja seperti: pencurian, penggunaan narkotika, pelecehan seksusal, pembunuhan, diskriminasi dan kejadian yang sering terjadi pada dua tahun terakhir sampai saat ini adalah banyaknya siswa yang berbuat tidak sopan kepada guru dikarnakan masih rendahnya moral dan etika dalam diri siswa. Dengan melihat fenomena tersebut dari situlah banyak pendidikan yang bertransformasi dengan tujuan pembenahan moral dan karakter anak, salah satunya adalah penerapan sistem full day school oleh beberapa sekolah di Indonesia.

Berdasarkan dari kasus-kasus yang telah terjadi pada kalangan remaja, hal seperti itu adalah suatu permasalahan yang urgent karena jika hal ini terus terjadi akan merusak moral pada diri siswa, berdampak negatif, merusak generasi bangsa dan keberkahan dalam memperoleh ilmu, dari situlah peneliti mencoba mengambil sikap atau tindakan apa yang harus diperbaiki agar pendidikan di Indonesia semakin maju. 
MI Khadijah Malang merupakan salah satu sekolah yang menerapkan sistem full day school yang berlangsung selama satu hari penuh dengan mengemas seluruh program pembelajaran dan kegiatan siswa disekolah dalam sebuah sistem pendidikan yang bernuansa islam, sehingga pembelajaran dimulai pukul 06.4515.00 WIB. Dengan memberikan waktu tambahan untuk siswa mendalami ilmu agama seperti belajar membaca al-quran sesuai dengan tingkatan kemampuan siswa dan pendalaman pengetahuan tentang agama seperti yang sudah diterapkan oleh MI Khadijah.

Selain itu di MI Khadijah sendiri siswa dibiasakan untuk hidup disiplin, tanggung jawab serta membudayakan akan kesadaran kebersihan lingkungan sekolah, membiasakan siswa untuk berperilaku sopan dan santun. Dan hal seperti itu tidak hanya diberlakukan kepada murid saja melainkan juga kepada semua dewan guru dan staf yang bekerja disekolah. Di MI Khadijah juga membiasakan penerapan budaya sekolah dengan tujuan agar peserta didik memiliki karakter yang baik dan memiliki rasa kepedulian terhadap diri sendiri, orang lain maupun lingkungan disekitar.

Berdasarkan hasil data/fenomena yang terjadi bahwasanya penulis sangatlah tertarik apabila melihat kondisi yang sedang terjadi untuk dilakukan sebuah penelitian yang lebih mendalam kaitanya dengan penerapan program full day school dalam mengembangkan karakter peserta didik pada tingkatan dasar. Dengan melihat langsung bagaimana karakter siswa-sisiwi di MI Khadijah, dan bagaimana penerapam program full day school serta faktor-faktor yang menjadi pendukung dan penghambat pada saat pelaksanaan.

\section{Metode}

Dalam penelitian ini akan mengkaji dan mendeskripsikan tentang penerapan program full day school dalam mengembangkan karakter peserta didik di MI Khadijah Malang. Yang menjadi fokus adalah karakter peserta didik, proses penerapan full day school, faktor-faktor pendukung dan penghambat baik dari segi nilai maupun sikap. Sesuai dengan hal tersebut maka penelitian ini menggunakan kualitatif deskriptif.

Lexy J. Meleong (2010:6) di artikan "penelitian kualitatif sebagai penelitian yang bermaksud untuk memahami fenomena tentang apa yang dialami oleh subjek penelitian, misalnya pada perilaku, persepsi, motivasi, secara holistik dengan cara deskripsi dalam bentuk kata-kata, bahasa pada suatu konteks yang alamiah dengan memanfaatkan berbagai metode alamiah". Jadi kualitatif deskripstif adalah data yang didapatkan dari hasil wawancara, dokumentasi, catatan laporan, atau sama 
halnya dengan penelitian deskripstif pada umunya yang berisi suatu pendeskripsian secara analisis terhadap peristiwa atau proses pada lingkungan.

Dan jenis penelitian yang digunakan adalah jenis studi kasus. "Adapun studi kasus adalah suatu metode untuk memahami individu yang dilakukan secara integrative dan komprehensif agar memperoleh pemahaman yang mendalam tentang individu tersebut beserta masalah yang dihadapi dengan maksud tujuan masalahnya dapat terselesaikan dan memperoleh perkembangan yang baik" (Susilo Rahardjo dan Gudnarto, 2011 : 250).

Pelaksanaan penelitian dilakukan mulai pada tanggal 15 April 2019 sampai pada tanggal 9 Mei 2019 di MI Khadijah Kota Malang yang terletak di Jl. Arjuno No. 19 A Kauman Klojen, Kota Malang. Dalam penelitian kualitatif kehadiran peneliti mutlak diperlukan untuk turun langsung ke lokasi tempat penelitian, karena peneliti merupakan bagian penting dari komponen guna untuk melihat secara langsung kondisi lingkungan dan kevalidan dalam pengumpulan data. Target atau sasaran dalam penelitian ini adalah pada siswa di MI Khadijah Malang dan yang menjadi subjek penelitian adalah Kepala Madrasah, waka kurikulum sekolah dan bagian keamanan sekolah dan beberapa siswa.

Tehnik pengumpulan data dalam penelitian kualitatif adalah menggunakan tehnik instrumen wawancara, observasi dan dokumentasi. Dan dalam tehnik analisis data Menurut Sugiyono ( 2012 : 89 ) "analisis data adalah proses mencari dan menyusun data secara sistematis, data yang diperoleh dari hasil wawancara catatan dilapangan dan dokumentasi, kemudian menyusun kedalam pola dan memilih mana yang penting dan yang akan dipelajari dan membuat kesimpulan sehingga mudah dipahami oleh diri sendiri maupun orang lain". Oleh sebab itu menggunakan tiga tahapan yaitu reduksi data, display data, dan verivikasi data. Dan untuk pengecekan keabsahan data menggunakan pengamatan jangka panjang, melakukan wawancara lebih mendalam, kajian kasus negatif, pengecekan sejawat, dan triangulasi.

\section{Hasil dan Pembahasan}

Hasil dari wawancara oleh beberapa pihak yang bersangkutan dan hasil dari observasi di MI Khadijah tentang penerapan sistem full day school dalam mengembangkan karakter peserta didik dapat dijabarkan sebagai berikut

\section{Pengembangan karakter siswa di MI Khadijah}

Menurut Creasy dalam Zubaedi (2012:102) mengartikan "pendidikan karakter sebagai upaya mendorong peserta didik tumbuh dan berkembang dengan kompetensi berpikir dan berpegang teguh pada prinsip-prinsip moral dalam 
hidupnya serta mempunyai keberanian melakukan yang 'benar' meskipun dihadapkan dengan berbagai tantangan".

Penerapan pendidikan karakter melalui pembelajaran dan kegiatan ekstrakurikuler belum sepenuhnya memberikan hasil seperti apa yang diharapkan pemerintah terutama lembaga sekolah, terbukti masih banyaknya sikap peserta didik yang tidak menghormati orang yang lebih tua dan menyayangi yang lebih muda, terlambat datang sekolah, tidak mengerjakan PR, malas belajar. Terlebih lagi teknologi yang semakin maju akan memberikan banyak dampak pada peserta didik baik dikalangan sekolah dasar, sekolah menengah pertama dan sekolah menengah atas dan mereka sudah pasti mengerti tentang media sosial, internet, game online dan lain-lain.

Dari hasil penelitian yang dilakukan di MI Khadijah terkait karakteristik siswa-siswi disana secara garis garis besar tergolong siswa yang mudah untuk diarahkan, mudah untuk dikondisikan tergantung guru mau diarahkan kemana siswa-siswi itu, dalam artian guru sebagai nahkoda dan siswa sebagai penumpang. Dan untuk menghadapi siswa yang aktif maupun pasif guru memiliki cara tersendiri untuk mengatasinya dengan cara berbeda-beda dari guru satu dengan guru yang lain. Dan dalam upaya untuk mengembangkan karakter MI Khadijah pada peserta didik dengan melalui pembiasaan setiap hari disekolah diantaranya:

a. Pembiasaan budaya 5S disekolah dimulai dari pagi hari ketika siswa mulai datang ke sekolah disambut dengan sebagian dewan guru untuk bersalaman dengan siswa dihalaman sekolah.

b. Pembiasaan siswa untuk sholat duha setiap pagi, kelas 1 dan kelas 2 untuk sholat dhuha dilaksanakan terlebih dahulu sebelum memulai pelajaran, dengan dituntun bacaanya oleh guru dikarnakan mereka masih pemula perlu adanya pembelajaran. Untuk kelas 3 sampai kelas 6 dilaksanakan pada waktu menjelang istirahat secara berjamaah, ketika didalam masjid siswa tetap dalam pendampingan dewan guru.

c. Pembiasaan kedisiplinan, kemandirian dan tanggung jawab dalam diri siswa bahwa sekolah memiliki kebijakan tersendiri jika ada siswa yang melanggar tata tertib sekolah ataupun tata tertib dikelas maka harus diberikan sanksi sesuai perjanjian yang telah disepakati.

d. Memasukkan konsep pendidikan karakter dalam proses pembelajaran pada mata pelajaran agama seperti akidah akhlak.

e. Dalam melatih pembiasaan karakter maka sekolah memiliki semboyan tersendiri yaitu "memberikan contoh akan lebih baik dari pada sekedar 
menasehati" jadi para dewan guru senantiasa memberikan contoh yang baik kepada peserta didik".

Karakter dapat dikembangkan melalui tiga tahapan yaitu: 1) awal pada tahap pengetahuan (knowing) dalam tahap ini peserta didik dibekali ilmu pengetahuan tentang nilai-nilai pendidikan karakter dan pada tahap ini memiliki ranah pada aspek kognitif. 2) Pada tahap kedua yaitu pelaksanaan (acting) memasuki tahap pelaksanaan memiliki ranah tentang penentuan sudut pandang tentang nilai-nilai karakter, penguatan emosi bagaimana siswa dalam menerima nilai-nilai pendidikan karakter. 3) Dan tahap ketiga adalah kebiasaan (habit) dalam tahap ini peserta didik dibiasakan untuk menerapkan nilai-nilai karakter sejak usia dini, serta memiliki ranah dalam keberanian mengambil sikap (moral action).

Menurut Sulistiono (2017:98) menjelaskan bahwa "pada era globalisasi peran guru sekarang bukan hanya sekedar mentransfer ilmu pengetahuan saja melainkan pada saat yang sama guru juga diharapkan mampu membentuk karakter peserta didik".

Dalam hal ini untuk membentuk karakter siswa maka MI Khadijah memiliki cara tersendiri untuk mengembangkannya dengan melalui budaya sekolah $6 \mathrm{~S}$ (salam, sapa, senyum, salim, sopan dan santun), selain itu juga menerapkan sikap bertanggung jawab, disiplin, mandiri, serta pembelajaran sholat 5 waktu dan sholat sunnah duha pada setiap harinya. Dalam pembiasaan karakter tentunya harus ada pendampingan yang intensif oleh guru dalam setiap kegiatan disekolah.

\section{Penerapan program full day school dalam mengembangkan karakter peserta didik}

Penerapan program full day school di MI Khadijah sudah berjalan mulai 2 tahun ini dimulai pada tahun ajaran 2017 dan memasuki tahun ke 3 di tahun ajaran baru mendatang. Dan hal yang melatar belakangi penerapan full day school adalah karna adanya Peraturan Menteri Pendidikan dan Kebudayaan Nomor 23 tahun 2017 tentang lima hari sekolah, maka dari itu adanya kesepakatan dari hasil musyawarah dewan guru dan kepala madrasah bahwasanya setuju apabila MI Khadijah menerapkan program full day school dengan belajar 5 hari disekolah.

Tujuan dari penerapan program full day school sendiri adalah agar siswa memiliki waktu istirahat dirumah lebih banyak dari biasanya, dan menggunakan waktu lima hari sekolah untuk memaksimalkan belajar dengan baik, , selain itu dalam mengembangkan karakter peserta didik diintegrasikan kedalam mata pelajaran agama Akidah Akhlak, pengembangan minat bakat atau ekstrakurikuler, menerapkan pembiasaan dalam budaya sekolah, kegiatan spontan. Adapun 
tambahan dari tujuan penerapan program full day school di MI Khadijah target utamanya adalah pembentukan karakter siswa yang meliputi:

a. Dapat mengembangkan karakter peserta didik baik secara sikap (akhlakul karimah) maupun perbuatan dalam beribadah (ubudiyah).

b. Dapat mengembangkan budaya literasi membaca dengan maksimal pada waktu pagi hari.

c. Menambah jam mengaji atau belajar membaca al-quran pada siswa dan hal itu menjadi salah satu ikon tersendiri di MI Khadijah Malang.

d. Pembelajaran sholat 5 waktu pada siswa secara berjamaah dimulai dari sholat dhuha berjamaah, sholat dhuhur berjamaah, dan sholat asar berjamaah dengan diiringi dzikir bersama dan kegiatan seperti itu dilakukan berulang pada setiap harinya.

Program full day school yang dijalankan sekolah selama satu hari penuh hal ini merupakan program pendidikan yang seluruh aktivitasnya berada didalam sekolah mulai dari pagi hari sampai sore hari. Menurut Ragella (2011:43) "untuk meningkatkan pencapaian tujuan pendidikan dan pembelajaran dengan penambahan jam pelajaran agar siswa mampu mendalami sebuah mata pelajaran dengan jatah waktu yang proporsional selama sehari penuh".

Dalam hal lain upaya mengembangkan karakter peserta didik yaitu dengan menerapkan pembelajaran sholat 5 waktu dan sholat duha yang dilakukan secara rutin setiap harinya dengan berjamaah dan adanya penambahan jam mengaji, berdoa ketika hendak melakukan sesuatu (keluar kelas, masuk dan keluar masjid, sebelum dan sesudah makan, selesai berwudu', dan memulai serta mengakhiri belajar). Selain itu pada hari jum'at ketika para laki-laki menunaikan sholat jum'at, disekolah mengadakan kegiatan keputrian yang ditujukan kepada semua siswi putri sambil menunggu sholat duhur, dengan tujuan menambahkan wawasan religius kepada peserta didik. Semua kegiatan yang diterapkan adalah semata-mata agar peserta didik merasakan cinta kepada Allah SWT, hidup disiplin, bertanggung jawab, sopan santun dan berakhlakul karimah.

Hal tersebut sesuai dengan apa yang diungkapkan oleh Daryanto (2013:7) bahwasanya untuk membentuk karakter anak yang baik yaitu bisa dilakukan melalui tiga tahapan yang pertama terapi kognitif dengan cara memperbaiki cara berfikir, dengan mengosongkan pikiran-pikiran negatif dan menumbuhkan atau memasukkan pemikiran yang berpengaruh positif, tahap yang kedua yaitu melalui terapi mental dengan cara memberikan pengarahan yang jelas dan positif dengan dilakukan secara rutin dan berkelanjutan, agar anak memiliki mental yang kuat dengan mengembangkan dasar-dasar nilai pendidikan karakter, tahap yang ketiga 
adalah terapi jasmani yaitu memadukan tiga unsur untuk memenuhi kebutuhan fisiknya tiga unsur tersebut diantaranya: memilih makanan yang sehat dan bergizi, istirahat cukup, olahraga.

\section{Faktor pendukung dan penghambat penerapan full day school dalam mengembangkan karakter peserta didik}

Disetiap awal program pastilah menuai pro dan kontra dikalangan masyarakat tetapi bukan berarti berhenti sampai disitu dan bukan menjadi penghambat dalam menuju proses, tergantung bagaimana cara mensiasati agar program yang dijalankan dapat berjalan dengan baik dan maksimal, dalam menjalankan kebijakan-kebijakan proses pendidikan tersebut diantara kendalakendala tersebut ialah :

a. Dilihat faktor intern (di sekolah)

Faktor yang berasal dari lembaga adalah kurangnya fasilitas untuk pengembangan peserta didik, kondisi siswa yang mudah merasa cepat lelah dikarnakan masih pemula dan merasa ngantuk. Ekstrakurikuler pramuka yang awalnya dilaksanakan pada hari sabtu diganti menjadi hari jumat sore dikarnakan banyaknya siswa yang tidak mengikuti ekstrakurikuler wajib maka sekolah memberi kebijakan untuk diganti hari.

b. Dilihat dari faktor ekstern (keluarga dan lingkungan)

Faktor yang berasal dari luar sangat cepat mempengaruhi diri siswa dalam penerapan full day school masih banyak orang tua yang merasa khawatir pada anaknya dikarnakan sekolah yang dilaksanakan selama satu hari penuh akan membuat diri siswa mengalami kelelahan dan stres, dalam pembentukan karakter siswa akan mudah terpengaruh pada lingkungan masyarakat terutama ketika libur panjang, komentar negatif dari orang tua siswa, terjadinya pro dan kontra dikalangan masyarakat dengan penerapan full day school.

Dalam penerapan full day school dengan mengembangkan karakter peserta didik dalam hal-hal yang menjadi faktor pendukung adalah:

a. Semangatnya dari dewan guru dalam mendampingi siswa-siswi selama disekolah.

b. Keteladanan guru-guru dalam menerapkan kedisiplinan, bertanggung jawab, kasih sayang.

c. Latar belakang sekolah yang mengedepankan sikap religius.

d. Selain itu sebagian dari wali murid sudah mulai menyadari manfaat dari penerapan program full day school terutama dalam nilai-nilai karakter siswa dari situ mulailah mendapat dukungan dari wali murid. 


\section{Simpulan}

Dari penjelasan yang telah dijabarkan di pembahasan dari hasil penelitian yang dilakukan oleh peneliti maka dapat disimpulkan sebagai berikut:

1. Karakter peserta didik di MI Khadijah Malang secara garis besar masih tergolong siswa yang mudah dikondisikan, mudah diberi pengarahan tergantung guru mau di arahkan kemana karna guru sebagai nahkoda dan peserta didik sebagai penumpang. Terlihat ketika melaksanakan kegiatan rutinan seperti sholat berjamaah, menerapkan budaya 6S (salam, sapa, salim, sopan, santun, senyum), membaca doa ketika akan dan selesai melakukan sesuatu tanpa disuruh, disiplin, dapat bertanggung jawab dan mulai bisa untuk mandiri secara rutin hal itu dilakukan dari suatu pembiasaan, walaupun begitu guru harus tetap memberikan pendampingan yang intensif pada peserta didik disetiap kegiatan disekolah.

2. Penerapan full day school di MI Khadijah sendiri memiliki tujuan dapat memaksimalkan belajar siswa selama 5 hari sekolah, selain itu nilai plus dari penerapan full day school adalah dapat terus mengembangkan karakter peserta didik dengan memiliki akhlakul karimah, menambah waktu mengaji, mengoptimalkan kegiatan ekstrakurikuler.

3. a. Adapun faktor pendukung dalam penerapan full day school adalah semangatnya pendidik dalam mendampingi siswa-siswi selama disekolah, keteladanan pendidik untuk hidup disiplin, bertanggung jawab dan kasih sayang, latar belakang sekolah yang mengedepankan sikap religius, sebagian dari wali murid sudah menyadari manfaat dari penerapan full day school disekolah.

b. Dan faktor penghambat yang pertama pada faktor intern (sekolah) yaitu masih belum lengkpanya fasilitas sekolah untuk pengembangan peserta didik agar tidak mudah bosan selama disekolah, dan faktor ekstern (orang tua dan masyarakat) yaitu dari orang tua yang pada awalnya masih mengkhawatirkan anaknya ketika diterapkan full day school ditakutkan siswa akan mengalami setres, adanya komentar negatif dari orang tua dan masyarakat mengenai penerapan 5 hari sekolah.

\section{Daftar Rujukan}

Daryanto dan Suryantri Darmiatun, S. Si., M.T. (2013) Implementasi pendidikan karakter di sekolah. Yogyakarta: Penerbit Gava Media. 
Islami, N. Arizka. (2016). Implementasi program pendidikan full day school di MI Muhammdiyah Karanglo Kabupaten Banyumas. Banyumas: Tidak di terbitkan.

Moleong, L.J. (2010). Metodologi Penelitian Kualitatif. Bandung: PT Remaja Rosdakarya.

Munawaroh, Siti. (2015). Efektifitas program full day school dalam pembinaan karakter siswa di SMP Wahid Hasyim Kota Malang. Skripsi. Universitas Islam Malang

Sa'adah, Alfi. (2018). Implementasi full day school dalam membentuk kualitas ahlak siswa di SD Al-Gontory Tulungagung. Jurusan pendidikan agama islam: IAIN Tulungagung

Septiana, Ragella. (2011). Pengelolaan pembelajaran full day school di SD Budi Mulia 2 Yogyakarta. Skripsi. Universitas Negri Yogyakarta.

Setiawan, A., \& Sulistiani, I.R. (2019). Pendidikan nilai budaya dan karakter dalam pembelajaran matematika dasar pada SD/MI. Elementaris: Jurnal ilmiah $\begin{array}{lllll}\text { pendidikan dasar } & \text { islam, } & \text { hlm. } & 36\end{array}$ http://riset.unisma.ac.id/index.php./fai/article/view/

Sulistiono, M. (2017). Quo vadis guru pendidikan agama islam dalam arus globalisasi. Dalam Bakri, Maskuri (Ed), Pendidikan islam dalam tantangan golbalisasi (hlm.96-98). Tangerang Selatan: Nirmana Media

Sugiyono. (2012). Metode Penelitian Kuantitatif, Kualitatif dan R\&D. Bandung: Alfabeta

Sudarsa. (2013). Pancasila Sebagai Rumah Bersama. Jakarta:PT. Wahana Semesta Intermedia

Zubaedi. (2012). Desain Pendidikan Karakter. Jakarta: Kencana 